\title{
Chromosome 13q deletion with Waardenburg syndrome: further evidence for a gene involved in neural crest function on $13 \mathrm{q}$
}

\author{
G Van Camp, M N Van Thienen, I Handig, B Van Roy, V S Rao, A Milunsky, \\ A P Read, C T Baldwin, L A Farrer, M Bonduelle, L Standaert, F Meire, P J Willems
}

Center for Human Genetics, Boston University School of Medicine, Boston,

USA

A Milunsky

C T Baldwin

\section{University}

Department of

Medical Genetics,

St Mary's Hospital,

Manchester, UK

A P Read

Department of Medical Genetics, University Hospital of the Free University of Brussels, Brussels, Belgium

M Bonduelle

Institute Spermalie, Bruges, Belgium

L Standaert

Department of Ophthalmology, University of Ghent, Ghent, Belgium F Meire

Correspondence to: Dr Van Camp.

Received 9 August 1994 Revised version accepted for publication 27 February 1995

\begin{abstract}
Department of Medical Genetics, University of Antwerp, Universiteitsplein 1, B-2610 Antwerp, Belgium

G Van Camp

$M$ N Van Thienen

I Handig

B Van Roy

P J Willems

Department of Neurology, Boston University School of Medicine, Boston, USA

V S Rao

L A Farrer

Abstract

Waardenburg syndrome (WS) is an autosomal dominant disorder characterised by pigmentary abnormalities and sensorineural deafness. It is subcategorised into type 1 (WS1) and type 2 (WS2) on the basis of the presence (WS1) or absence (WS2) of dystopia canthorum. WS1 is always caused by mutations in the PAX3 gene, whereas WS2 is caused by mutations in the microphthalmia (MITF) gene in some but not all families. An association of WS symptoms with Hirschsprung disease (HSCR) has been reported in many families. We report here a patient with characteristics of WS 2 and a de novo interstitial deletion of chromosome 13q. We also describe a family with two sibs who have both WS2 and HSCR. In this family, all possible genes for WS and HSCR, but not chromosome 13q, could be excluded. As an association between chromosome $13 q$ and HSCR/WS has been reported previously, these data suggest that there is a gene on chromosome 13q that is responsible for WS or HSCR or both.
\end{abstract}

(f Med Genet 1995;32:531-536)

Waardenburg syndrome (WS) is an autosomal dominant disorder, characterised by pigmentary abnormalities of the hair, eyes, and skin. These include a white forelock, premature greying of the hair, heterochromia irides, hypopigmented irises, and white skin patches. Sensorineural hearing impairment is present in 25 to $50 \%$ of the patients. With a population frequency of approximately $1 / 40000$, WS is responsible for about $2 \%$ of cases of congenital deafness. ${ }^{1}$ WS is subdivided into type 1 (WS1) and type 2 (WS2) on the basis of the presence or absence of dystopia canthorum. ${ }^{2}$

After the description of a child with WS1 and a de novo inversion of $2 \mathrm{q} 35-\mathrm{q} 37,{ }^{3}$ linkage analysis in several families localised a WS1 gene to this region. ${ }^{4-6}$ As the Splotch mutation, located in the syntenic region in the mouse, gives rise to white spotting, it has been suggested that WS and Splotch are homologous. The Splotch phenotype is caused by a mutation in the mouse Pax 3 gene, a member of the paired box gene family, known to be involved in embryonic development. ${ }^{7}$ Many mutations have now been found in the homologous human PAX3 gene in different WS1 famil- ies. ${ }^{8-10}$ Pooled data from the Waardenburg consortium indicate that all WS1 families are linked to PAX3. ${ }^{11}$

One form of WS2 has been localised to chromosome 3p12-p14.1 by linkage analysis. ${ }^{12}$ The MITF gene, the human homologue of the mouse microphthalmia (mi) gene, is located in this region. ${ }^{13}$ Mice with mi mutations show reduced pigmentation, microphthalmia, and hearing loss among other abnormalities. Mutations in the MITF gene have recently been found in patients in two WS2 families. ${ }^{14} \mathrm{How}-$ ever, WS2 is genetically heterogeneous, and some families are not linked to the locus on chromosome 3.

In addition to WS 1 and WS2, WS type 3 has been described. WS3, or Klein-Waardenburg syndrome, is an autosomal dominant trait characterised by a WS type 1 phenotype with additional upper limb abnormalities. ${ }^{1516}$ Linkage analysis has not been performed, but PAX3 mutations have been found in two type 3 families $^{17}$ (A P Read, unpublished data), and limb defects are now considered to be a rare pleiotropic manifestation of WS $1 .^{11}$ Many patients have been reported with WS2 symptoms in combination with congenital megacolon (Hirschsprung disease, HSCR). ${ }^{18-23}$ The parents of these patients are unaffected and often consanguineous. For this poorly defined, heterogeneous group with apparent recessive inheritance, the term WS type 4 has been proposed.

WS and HSCR are part of a group of diseases called neurocristopathies, which are caused by an abnormal migration of neural crest cells during embryonic development. Apart from the PAX3 and MITF genes, mutations in two proto-oncogenes are known causes of neurocristopathies. Loss of function mutations in the RET proto-oncogene commonly causes HSCR without pigmentary disturbances or deafness, which is inherited as a dominant condition with reduced penetrance. ${ }^{2425}$ Mutations in the cKIT proto-oncogene cause piebaldism, characterised by congenital white patches of skin and hair. ${ }^{26}$

We identified a de novo interstitial deletion of chromosome 13q in a boy with features of WS2, suggesting that a WS gene might be located in the deleted region of chromosome 13q. Although a gene responsible for WS in the deleted region on chromosome 13 could be excluded in several WS2 families, this chromosomal region could not be excluded in a family with WS2 and HSCR. 


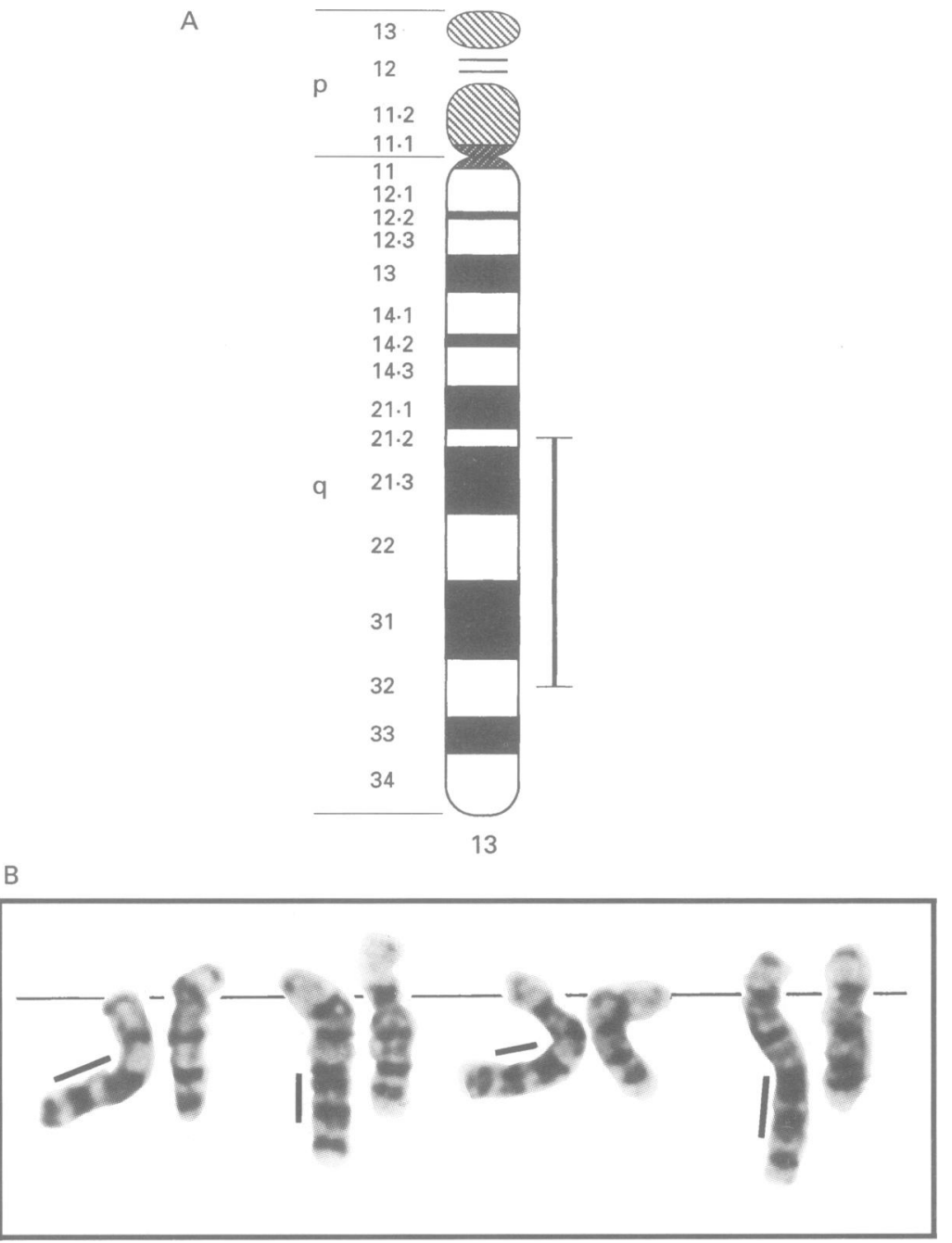

Figure 1 (A) Idiogram of chromosome 13. The vertical bar indicates the deleted region in the WS2 patient. (B) Partial GTB banded karyotypes of the WS2 patient. The deleted chromosome 13 is shown on the right of each chromosome pair, and the deleted band is indicated on the normal chromosome.

\section{Patients and methods}

WS2 PATIENT WITH A CHROMOSOME 13 DELETION

A 6 year old boy presented with unilateral segmental heterochromia of the iris, hypopigmentation of the eye fundus, sensorineural deafness, and delayed psychomotor development (performance IQ was 62 on WPPSI

Table 1 Genotype of the WS2 patient and his parents for chromosome 13 microsatellite markers. Alleles are numbered arbitrarily. Markers are ordered from centromere to telomere, according to the genetic maps of Bowcock et al ${ }^{2831}$ and the Cooperative Human Linkage Center (CHLC), ${ }^{36}$ and the physical map of White et al ${ }^{30}$

\begin{tabular}{|c|c|c|c|c|c|}
\hline \multirow[t]{2}{*}{ Locus } & \multirow{2}{*}{$\begin{array}{l}\text { Cytogenetic } \\
\text { localisation }\end{array}$} & \multicolumn{3}{|c|}{ Genotype } & \multirow[t]{2}{*}{ Conclusion } \\
\hline & & Father & Patient & Mother & \\
\hline $\begin{array}{l}\text { D13S126 } \\
\text { D13S118 } \\
\text { D13S227* } \\
\text { D13S228* } \\
\text { D13S133* } \\
\text { D13S137* } \\
\text { D13S119 } \\
\text { D13S134 } \\
\text { D13S131 } \\
\text { D13S144 } \\
\text { D13S317 } \\
\text { D13S121 } \\
\text { D13S140 } \\
\text { D13S125 } \\
\text { D13S122 }\end{array}$ & $\begin{array}{l}\text { 13q14.1-q14.2 } \\
13 q 14.1-q 14.2 \\
13 q 14.3 \\
13 q 14.3 \\
13 q 14.3 \\
13 q 14.3 \\
13 q 14.3-q 22 \\
13 q 14.3-q 22 \\
13 q 14.3-q 22 \\
13 q 14.3-q 22 \\
13 q 31 \\
13 q 32-q 33 \\
13 q 31-q 32 \\
13 q 31-q 32\end{array}$ & $\begin{array}{l}12 \\
22 \\
13 \\
23 \\
38 \\
45 \\
11 \\
35 \\
46 \\
22 \\
35 \\
22 \\
12 \\
21 \\
13\end{array}$ & $\begin{array}{l}12 \\
2 \text { or } 22 \\
17 \\
3 \text { or } 33 \\
35 \\
45 \\
1 \text { or } 11 \\
44 \\
4 \text { or } 44 \\
1 \\
4 \\
2 \text { or } 22 \\
13 \\
21 \\
14\end{array}$ & $\begin{array}{l}23 \\
12 \\
37 \\
23 \\
35 \\
55 \\
11 \\
34 \\
14 \\
12 \\
34 \\
21 \\
23 \\
31 \\
24\end{array}$ & $\begin{array}{l}\text { Not deleted } \\
\text { Not informative } \\
\text { Not deleted } \\
\text { Not informative } \\
\text { Not deleted } \\
\text { Not deleted } \\
\text { Not informative } \\
\text { Deleted } \\
\text { Not informative } \\
\text { Deleted } \\
\text { Deleted } \\
\text { Not informative } \\
\text { Not deleted } \\
\text { Not deleted } \\
\text { Not deleted }\end{array}$ \\
\hline
\end{tabular}

* These markers have been localised between D13S118 and D13S119 on a physical map. ${ }^{30}$ †The exact location of D13S144 relative to D13S134 and D1S131 is not known. ${ }^{28}$ $\$$ This marker is located $2 \mathrm{cM}$ proximal to D13S121 on the CHLC genetic map. ${ }^{36}$ scale). A linear skin depigmentation on the legs became evident after Wood lamp examination. Dystopia canthorum was not present ( $w$ index of 1.57). There were no signs of HSCR. Clinical examination of the parents showed no signs of WS.

WS2 FAMILIES

All WS2 families used in this study have been described previously. ${ }^{11}$

FAMILY WITH WS AND HSCR

The male proband of this family developed intestinal obstruction soon after birth. Laparoscopy confirmed the presence of a microcolon, which was shown to be the result of total colonic aganglionosis by microscopic examination. WS was suspected because of cutaneous piebaldism, a white forelock, white streaked eyebrows, white eyelashes, and isochromic pale blue eyes. Dystopia canthorum was absent. Profound bilateral sensorineural deafness was shown by an auditory brainstem response test. Ophthalmological examination showed a normal retina and no other anomalies. Histological examination of the achromatic skin showed a normal epidermis but an absence of melanocytes. Routine cytogenetic analysis did not show any abnormality. The family history included an older brother with similar features of WS who died from long segment HSCR. Neither parent nor three healthy sibs had any sign of WS on further examination. No consanguinity between the parents could be documented, although they both originated from a small Moroccan village of 600 inhabitants.

\section{CYTOGENETIC ANALYSIS}

Peripheral blood cultures of the WS2 patient and his parents were synchronised using the methotrexate/bromodeoxyuridine method. High resolution $G$ banding with trypsin/basic fuchsin (GTB) was performed according to Scheres et al. ${ }^{27}$

\section{MICROSATELLITE ANALYSIS}

The following polymorphic dinucleotide repeat chromosome $13 \mathrm{q}$ markers were typed: D13S126, D13S118，D13S227，D13S228, D13S133，D13S137，D13S119，D13S134, D13S131, D13S144, D13S317, D13S121, D13S140, D13S125, and D13S122. All these markers have been described before, ${ }^{28-30}$ and are integrated in the genetic ${ }^{2831}$ or physical ${ }^{30}$ map of chromosome 13. Experimental procedures for the amplification of microsatellites were as described. ${ }^{32}$ Microsatellite markers for the PAX3 gene, the RET gene, for markers D3S1261 and D3S1284 flanking the MITF gene, and for the GARB 1 marker, located $3 \mathrm{cM}$ proximal of the KIT gene on chromosome $4 \mathrm{q}$ were obtained from the Genome DataBase. ${ }^{33}$

\section{LINKAGE ANALYSIS}

Linkage analysis was performed as described, ${ }^{11}$ using the computer programs Liped ${ }^{34}$ and Link- 


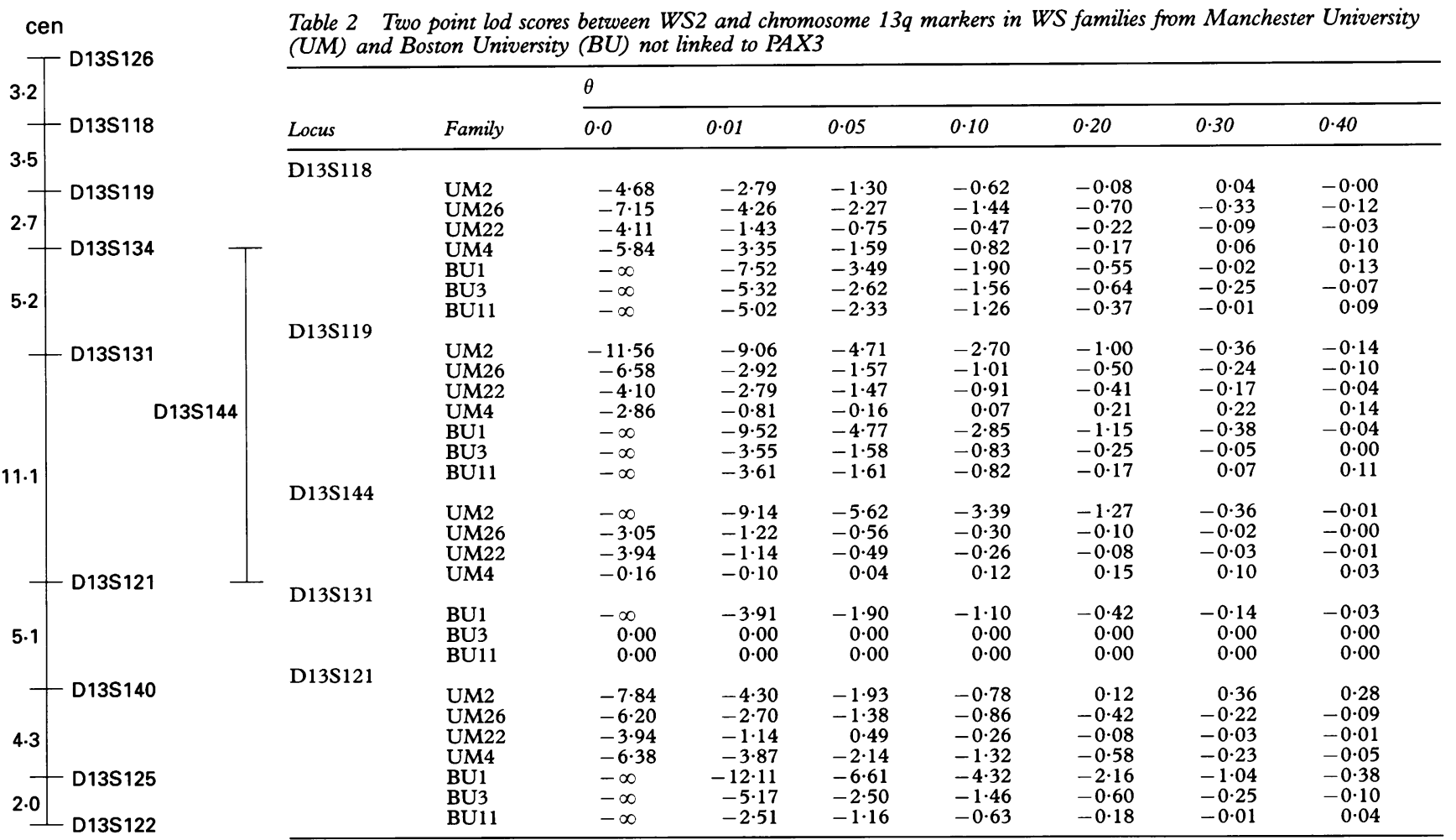

tel

Figure 2 Genetic map positions of the chromosome $13 q$ microsatellite markers used in this study, according to Bowcock. ${ }^{31}$ The sex averaged map is shown and distances are indicated in $\mathrm{CM}$. age. ${ }^{35}$ Penetrance was set at $93 \%$ in both sexes, and a gene frequency of 0.001 was assumed. In the multipoint linkage analysis, intermarker distances were used according to the sex averaged map of Bowcock et al. ${ }^{2831}$

\section{Results}

CYTOGENETIC ANALYSIS

Routine karyotyping of a boy with characteristics of WS2 showed an interstitial deletion of the long arm of chromosome 13. High resolution GTB banding showed that the breakpoints of the deletion were in 13q21.2

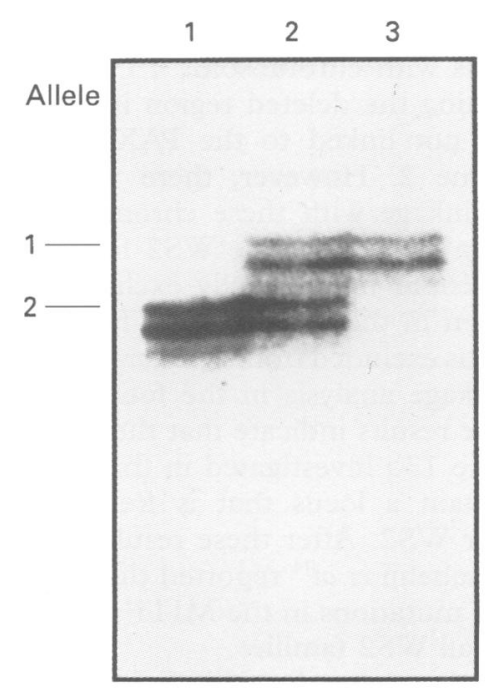

A

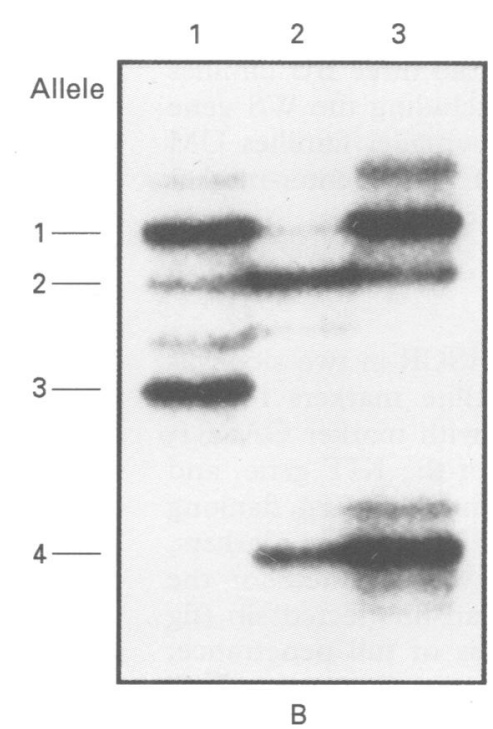

Figure 3 Autoradiograph illustrating the $C A$ repeat analysis of the WS2 patient (lane 3), his father (lane 1), and his mother (lane 2) for CA repeat markers D13S144 (A) and D13S122 (B). The patient shows a deletion of the paternal allele of D13S144, as he only has the maternal allele 1, whereas his father is homozygous for allele 2. The WS2 patient is heterozygous for D13S122, indicating that this marker is located outside the deletion. and $13 q 32$, respectively (fig 1 ). No abnormality was found in the parents.

MOLECULAR DELINEATION OF THE DELETION To correlate the $13 \mathrm{q}$ deletion with the genetic map, 15 microsatellite genetic markers spanning the deleted region on chromosme 13q were typed in the WS patient and his parents (table 1). These markers cover approximately $40 \mathrm{cM}$ of the long arm of chromosome $13 .{ }^{31} \mathrm{~A}$ genetic map containing most of these markers is given in fig 2 . The patient is heterozygous for the proximal markers D13S126, D13S227, D13S133, D13S137, and the three most distal markers D13S140, D13S125, and D13S122. Therefore, these loci are not deleted in the patient. No paternal allele of D13S134, D13S144, and D13S317 is present in the patient, indicating that these loci are deleted from the paternal chromosome 13 in the patient (fig 3). The remaining markers D13S118, D13S228, D13S119, D13S131, and D13S121 were not informative. This analysis limits the deleted interval to the region between markers D13S137 and D13S140, a region of less than $30 \mathrm{cM}$.

LINKAGE ANALYSIS IN WS2

Linkage analysis with chromosome 13q markers was carried out in seven WS2 families that are not linked to the PAX3 gene on chromosome $2 .{ }^{11}$ Four microsatellite markers spanning the deleted region were analysed (table 1 , fig 2). In the University of Manchester (UM) families, D13S118, D13S119, D13S144, and D13S121 were used. In the Boston University (BU) families, D13S131 was used instead of D13S144. The use of different markers should not affect the analysis since both D13S131 and 


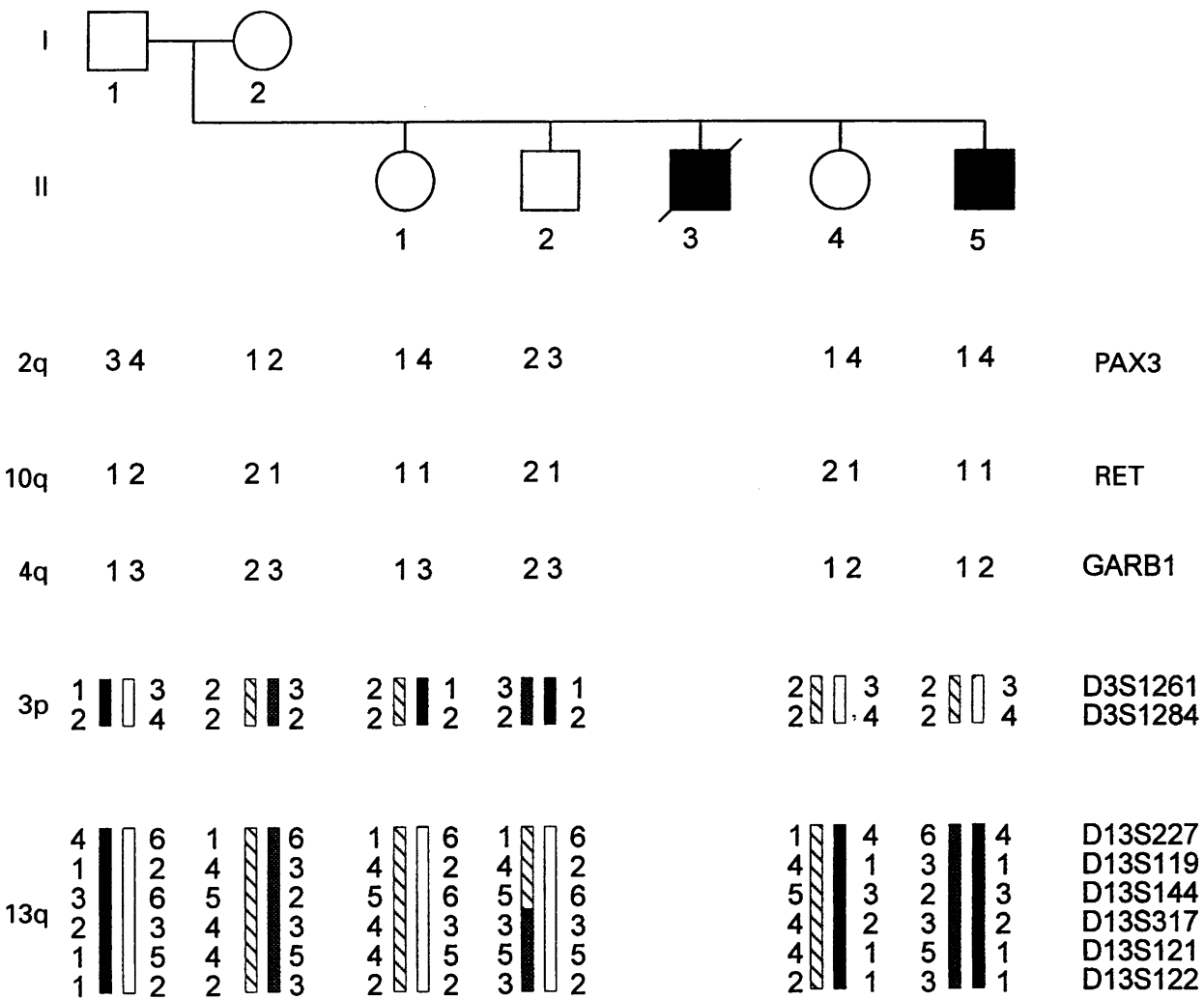

Figure 4 Pedigree structure of the family with WS and HSCR, typed with microsatellite markers for the PAX3 gene, Figure 4 Pedigree structure of the family with WS and HSCR, typed with microsatellite markers for the $P A X 3$ gene,
the RET gene, and the GARB1 marker close to the KIT gene $(A)$. Haplotypes are given for two chromosome 3 markers flanking the MITF gene and for six informative chromosome 13 genetic markers from the deleted region in the de novo WS2 patient (B).

D13S144 are unambiguously placed between D13S119 and D13S121. ${ }^{2831}$

Table 2 presents two point lod scores between these markers and WS 2 in seven different WS2 families. In none of the families tested was there evidence for linkage with chromosome 13q. Multipoint linkage analysis was performed independently in each family (data not shown). Lod scores below -2 were obtained for all inter-marker regions between D1S118 and D1S121 in all three BU families and in family UM 2, excluding the WS gene from this region. In the smaller families UM 26 , UM 22, and UM 4 not all inter-marker regions were formally excluded.

WS/HSCR FAMILY

A family with WS and HSCR in two sibs was analysed with microsatellite markers for the PAX3 and RET genes, with marker GARB1, located $3 \mathrm{cM}$ proximal of the KIT gene, and with markers D3S1261 and D3S1284, flanking the MITF gene (fig 4). For all these markers, an identical haplotype was obtained for the WS/HSCR patient and an unaffected sib (fig 4). Under the hypothesis of full penetrance, this excludes all four genes as the cause of WS/ HSCR in this family. The family was also typed for a number of chromosome 13q markers, spanning the deletion found in the de novo WS2 patient (fig 4). The patient and his unaffected sibs did not share a parental haplotype for the $13 \mathrm{q}$ markers, indicating that the in- volvement of this chromosomal region as a cause of the disease can not be excluded.

\section{Discussion}

In this study we describe a de novo interstitial deletion of the long arm of chromosome 13 in a patient diagnosed with WS2. This suggests that a gene responsible for WS2 is located in this deleted region. Therefore, we performed linkage analysis with chromosome 13 genetic markers spanning the deleted region in seven WS2 families not linked to the PAX3 gene on chromosome 2. However, there was no evidence for linkage with these chromosome 13q markers in either of these WS2 families. Although we could not formally exclude the complete region in the three smaller families, the WS gene was excluded from all inter-marker regions by linkage analysis in the four larger families. These results indicate that the region of chromosome $13 q$ investigated in this study does not contain a locus that is frequently responsible for WS2. After these results were obtained, Tassabehji et $a l^{14}$ reported that WS2 is the result of mutations in the MITF gene in some but not all WS2 families.

Recently, a new locus for HSCR has been mapped to chromosome 13q22 in a single large inbred family. The inheritance pattern in this family is unclear, and both recessive inheritance and dominant inheritance with reduced penetrance are possible. ${ }^{37}$ The gene causing HSCR in this family is located inside the chromosome 
13 region deleted in our patient. ${ }^{37}$ The authors also incidentally report characteristics similar to WS, including white forelock, bicoloured irides, hearing loss, and hypopigmentation of the skin, in a number of the HSCR patients. Although the authors state that it is likely that these WS characteristics segregate separately from HSCR in this pedigree, the same pedigree has been published independently by others as a combined HSCR/WS kindred resulting from pleiotropic effects of a single mutation. ${ }^{38}$ This suggested that a gene responsible for both HSCR and WS could be located in this chromosome 13 region.

We therefore analysed a small family with both WS and HSCR with genetic markers in this chromosome 13 region and with possible candidate genes, such as the PAX3, RET, MITF, and KIT genes. Assuming full penetrance, we were able to exclude PAX3, RET, MITF, and KIT mutations as the cause of WS and HSCR in this family. However, analysis with chromosome 13 markers spanning the deleted region in the de novo WS2 patient could not exclude this region. Although the family is too small to derive any linkage information, a chromosome 13q gene could very well be responsible for a combination of WS and HSCR. This is also supported by published data, as chromosome 13 deletions are present in several reports of patients with neural crest dysfunction. Apart from our present case, five cases have been reported of HSCR associated with deletion of the long arm of chromosome 13, with the breakpoints 13q21.2-qter, ${ }^{39}$ $13 \mathrm{q} 14.1-\mathrm{q} 22.3,{ }^{40} 13 \mathrm{q} 22.1-\mathrm{q} 32.1{ }^{41}$ 13q21.2$\mathrm{q} 32.3,{ }^{41}$ and $13 \mathrm{q} 32.3-\mathrm{q} 33.2 .^{42}$ None of these patients was reported to have symptoms of WS, although one did have heterochromia irides. ${ }^{43}$ Other patients with overlapping $13 \mathrm{q}$ deletions have been reported who did not have HSCR. ${ }^{4143}$ This variability is not incompatible with the presence on 13q of a WS/HSCR gene. It is possible that HSCR in these cases is a recessive entity unmasked by the deletion; in that case patients with a 13q deletion on one chromosome would only express WS/HSCR if they had a second mutation on the non-deleted chromosome. On the other hand, the inheritance could be dominant with reduced penetrance. Both hypotheses would adequately explain why some patients with $13 q$ deletions do not have HSCR. Also, patients with gross rearrangements of 2q35 deleting PAX3 do not necessarily show signs of WS. ${ }^{445}$

In summary, the findings from our study corrobate the published data from which it is clear that (1) WS is associated with HSCR in many cases, (2) HSCR is associated with $13 \mathrm{q}$ deletions, (3) a family with characteristics of both HSCR and WS shows linkage to chromosome $13 \mathrm{q} 22$. Our study shows that a patient with a 13q21.2-q32 deletion has characteristics of WS, and that WS and HSCR in two sibs of one family might be the result of a mutated gene in the same region of chromosome 13. Taken together, these data strongly suggest the existence of a gene on chromosome $13 q$ that is involved in neural crest cell migration, causing either HSCR, WS, or a combination of both.
The recessive mouse mutation piebald lethal, a mouse model for HSCR, is characterised by striking changes in coat pigmentation and the development of fatal aganglionic megacolon. ${ }^{46}$ The mutation is located on mouse chromosome 14 between the homologue of the human retinoblastoma gene, located on human $13 \mathrm{q} 14.2$, and the mouse homologue of the human tyrosine related protein 2 , located on human 13q31$32 .{ }^{47}$ If the human-mouse synteny is conserved throughout this region, the human homologue of the gene responsible for mouse piebald lethal is a very strong candidate for the gene involved in neural crest function in this region.

\section{Note added in proof}

After this paper was submitted, a mutation was reported ${ }^{48}$ in the endothelin-B receptor (EDNRB) gene in the large inbred HSCR family that is linked to $13 \mathrm{q} 22 .{ }^{3738}$ Simultaneously, a paper was published ${ }^{49}$ describing mutations in the mouse EDNRB gene producing megacolon and spotted coat colour. These data indicate that the gene on $13 q$ responsible for WS and HSCR is most likely EDNRB.

We thank Drs A Munnich and S Lyonnet for the genotyping of the chromosome 10 markers, and Drs $H$ Scheffer and $F$ Kooy for providing several chromosome 13 primers. Financial support from the Nationaal Fonds voor Wetenschappelijk Onderzoek (NFWO) to GVC, a grant from the University of Antwerp to GVC and PJW, NIH grant DC01848 to CTB and NIH contract 263-MD-117512 to LAF are gratefully acknowledged. GVC holds a postdoctoral research position with the NFWO. LAF was supported by a fellowship from the Alfred P Sloan Foundation.

1 Waardenburg PJ. A new syndrome combining developmental anomalies of the eyelids, eyebrows and nose root with pigmentary defects of the iris and head hair and with congenital deafness. Am f Hum Genet 1951;3: 195-253.

2 Arias S. Genetic heterogeneity in the Waardenburg syndrome. Birth Defects 1971;7:87-101.

3 Ishikiriyama S, Tonoki $\mathrm{H}$, Shibuya $\mathrm{Y}$, et al. Waardenburg syndrome type 1 in a child with de novo inversion (2) (q35q37.3). Am f Med Genet 1989;33:505-7.

4 Foy C, Newton V, Wellesley D, Harris R, Read A. Assignment of the locus for Waardenburg syndrome type I to human chromosome $2 \mathrm{q} 37$ and possible homology to the splotch mouse. Am f Hum Genet 1990;46:1017-23.

5 Asher JH, Morell R, Friedman TB. Waardenburg syndrome (WS): the analysis of a single family with a WSI mutation howing linkage to RFLP markers on human chromosom 2q. Am F Hum Genet 1991;48:43-52.

6 Farrer LA, Grundfast KM, Amos J, et al. Waardenburg syndrome (WS) type I is caused by defects at multiple loci, one of which is near ALPP on chromosome 2: first report of the WS consortium. Am $\mathcal{F}$ Hum Genet 1992;50: 902-13.

7 Epstein DJ, Vekemans M, Gros P. Splotch (Sp2H), a mutation affecting development of the mouse neural tube shows a deletion within the paired homeodomain of $\mathrm{Pax}$ 3. Cell 1991;67:767-74.

8 Tassabehii M, Read A, Newton VE, et al. Waardenburg syndrome patients have mutations in the human homologue of the Pax-3 paired box gene. Nature 1992;355: 635-6.

9 Baldwin CT, Hoth CF, Amos JA, da-Silva EO, Milunsky A. An exonic mutation in the HuP2 paired domain gene
causes Waardenburg syndrome. Nature 1992;355:637-8.

10 Morell R, Friedman TB, Moeljopawiro S, et al. A frameshift mutation in the Hup2 paired domain of the probable human homologue of murine $\mathrm{Pax} 3$ is responsible fo Waardenburg syndrome type 1 in an Indonesian family. Hum Mol Genet 1992;1:243-7.

11 Farrer LA, Amos KA, Asher JH, et al. Locus heterogeneity for Waardenburg syndrome is predictive of clinical subtypes. Am F Hum Genet 1994;55:728-37.

12 Hughes AE, Newton VE, Liu XZ, Read AP. A gene fo Waardenburg syndrome type 2 maps close to the human homologue of the microphthalmia gene at chromosome 3p12-p14.1. Nature Genet 1994;7:509-12.

13 Tachibana M, Perez-Jurado LA, Nakayama A, et al. Cloning of MITF, the human homolog of the mouse microphthalmia gene and assignment to chromosome 3p14.1-p12.3. Hum Mol Genet 1994;3:553-7.

14 Tassabehij M, Newton VE, Read AP. Waardenburg syndrome type 2 caused by mutations in the human mi15 Goodman RM, Lewithal I, Solomon A, Klein D. Upper 
limb involvement in the Klein-Waardenburg syndrome. Am f Med Genet 1982;11:425-33.

$16 \mathrm{Klein} \mathrm{D}$. Historical background and evidence for dominant inheritance of the Klein-Waardenburg syndrome (type inheritance of the Klein-Waardenb $\mathcal{f}$ Med Genet 1983;14:231-9.

17 Hoth CF, Milunsky A, Lipsky N, et al. Mutations in the paired domain of the human PAX 3 gene cause Kleinpaired domain of the human PAX 3 gene cause KleinWaardenburg syndrome (WS-III) as well as Waarden

18 Shah KN, Dalal SJ, Desai MP, et al. White forelock, pigmentary disorder of irides, and long segment Hirschsprung disease: possible variant of Waardenburg syndrome. $\mathcal{F}$ Pediatr 1981;99:432-5.

19 Meire F, Standaert L, De Laey JJ, Zeng LH. Waardenburg syndrome, Hirschsprung megacolon, and Marcus Gunn ptosis. Am $\mathcal{F}$ Med Genet 1987;27:683-6.

20 Till M, Bonnet JP, Lyonnet S, Guibaud P. Syndrome de Waardenburg type II: existe-t-il une forme recessive autosomique? Proceedings of the 4th European Meeting of Dysmorphology, Strasbourg 1993:59.

21 Ambani LM. Waardenburg and Hirschsprung syndromes. $\mathcal{F}$ Pediatr 1983;102:802.

22 Fried K, Beer S. Waardenburg's syndrome and Hirschsprung's disease in the same patient. Clin Genet 1980;18: sprung.

23 Omenn GS, McKusick VA. The association of Waardenburg syndrome and Hirschsprung megacolon. Am $\mathcal{f}$ Med Genet 1979;3:217-23.

24 Edery P, Lyonnet S, Mulligan LM, et al. Mutations of the Ret proto-oncogene in Hirschsprung's disease. Nature $1994: 367 \cdot 378-9$.

25 Romeo G, Ronchetto P, Luo Y, et al. Point mutations affecting the tyrosine kinase domain of the RET protooncogene in Hirschsprung's disease. Nature 1994;367: 377-8.

26 Spritz RA, Giebel LB, Holmes SA. Dominant negative and loss of function mutations of the c-kit (mast/stem cell growth factor receptor) proto-oncogene in human piebaldism. Am f Hum Genet 1992;50:261-9.

27 Scheres JM, Merkx GF, Hustinx TW. Prometaphase banding of human chromosomes with basic fuchsin. Hum Genet 1982;61:8-11.

28 Bowcock A, Osborne-Lawrence S, Barnes R, et al. Microsatellite polymorphism linkage map of human chromosatellite polymorphism linkage map

29 Petrukhin KE, Speer MC, Cayanis E, et al. A microsatellite genetic linkage map of human chromosome 13. Genomics genetic linkage

30 White A, Tomfohrde J, Stewart E, et al. A 4-5-megabase yeast artificial chromosome contig from human chromosome 13 q14.3 ordering 9 polymorphic microsatellites $(22$ sequence-tagged sites) tightly linked to the Wilson disease locus. Proc Natl Acad Sci USA 1993;90:10105-9.

31 Bowcock A. Report of the first international workshop on human chromosome 13 mapping. Cytogenet Cell Genet 1993;62:89-107.
32 Hughes A. Optimization of microsatellite analysis for genetic mapping. Genomics 1993;15:433-4.

33 Cuticchia AJ, Fasman KH, Kingsbury DT, Robbins RJ, Pearson PL. The GDB human genome

34 Ott J. Estimation of the recombination fraction in human pedigrees: efficient computation of the likelihood for
human linkage studies. Am f Hum Genet 1974;26:588-97.

35 Lathrop GM, Lalouel JM. Easy calculations of lod scores and genetic risks on small computers. Am $\mathcal{f}$ Hum Genet and genetic risk

36 Buetow KH, Weber JL, Ludwigsen S, et al. Integrated (he CEPH human genome-wide maps constructed using

37 Puffenberger EG, Kauffman ER, Bolk S, et al. Identity-bydescent and association mapping of a recessive gene for Hirschsprung disease on human chromosome 13q22. Hum Mol Genet 1994;3:1217-25.

38 Dow E, Cross S, Wolgemuth DJ, et al. Second locus for Hirschsprung disease/Waardenburg syndrome in a large Mennonite kindred. Am f Med Genet 1994;53:75-80.

39 Kiss P, Osztovics M. Association of $13 q$ deletion and Hirschsprung disease. F Med Genet 1989;26:793-4.

40 Sparkes RS, Sparkes MC, Kalina RE, et al. Separation of retinoblastoma and esterase $\mathrm{D}$ loci in a patient with sporadic retinoblastoma and del (13) (q14.1q22.3). Hum Genet 1984;68:258-9.

41 Lamont MA, Fitchett M, Dennis NR. Interstitial deletion of distal $13 \mathrm{q}$ associated with Hirschsprung disease. $\mathcal{F} \mathrm{Med}$ of distal 13q associated

42 Bottani A, Xie $Y$, Binkert $F$ Schinzel A A case of Hirschsprung disease with a chromosome 13 microdeletion, sprung disease with a chromosome 13 microdeletion, del(13) (q32.3q33.2): potential mapp

43 Brown S, Gersen S, Anyane-Yeboa K, Warburton D. Preliminary definition of a critical region of chromosome 13 in 932 . definition of a critical region of chrom and review of the literature. Am 7 Med Genet 1993;45:52-9.

44 Pasteris NG, Trask BJ, Sheldon S, Gorski JL. Discordant phenotypes of two overlapping deletions involving the PAX3 gene in chromosome 2q35. Hum Mol Genet 1993; 2:953-9.

45 Palmer CG, Heerema N, Bull M. Deletions in chromosome 2 and fragile sites. Am 7 Med Genet 1990;36:214-18.

46 Lane PW. Association of megacolon with two recessive spotting genes in the mouse. F Hered 1966;57:29-31.

47 Metallinos DL, Oppenheimer AJ, Rinchik EM, et al. Fine structure mapping and deletion analysis of the murine piebald locus. Genetics 1994;136:217-23.

48 Puffenberger EG, Hosoda K, Washington S, et al. A missense mutation of the endothelin-B receptor gene in multigenic mutation of the endothelin-B receptor gene in

49 Hosa K, Hammer RE, Richardson JA, et al. Targeted and natural (piebald-lethal) mutations of endothelin-B receptor gene produce megacolon associated with spotted coat colour in mice. Cell 1994;79:1267-76. 